University for Business and Technology in Kosovo

UBT Knowledge Center

Oct 28th, 9:00 AM - 10:30 AM

\title{
The definition of a 'place of effective management' at article 4 paragraph 3 of the 2014 OECD Model Tax Convention
}

Shkumbin Asllani

University for Business and Technology, shkumbin.asllani@ubt-uni.net

Follow this and additional works at: https://knowledgecenter.ubt-uni.net/conference

Part of the Law Commons

\section{Recommended Citation}

Asllani, Shkumbin, "The definition of a 'place of effective management' at article 4 paragraph 3 of the 2014 OECD Model Tax Convention" (2017). UBT International Conference. 219.

https://knowledgecenter.ubt-uni.net/conference/2017/all-events/219

This Event is brought to you for free and open access by the Publication and Journals at UBT Knowledge Center. It has been accepted for inclusion in UBT International Conference by an authorized administrator of UBT Knowledge Center. For more information, please contact knowledge.center@ubt-uni.net. 


\title{
The definition of a "place of effective management" at article 4 paragraph 3 of the 2014 OECD Model Tax Convention
}

\author{
Shkumbin Asllani \\ ${ }^{1}$ UBT - Higher Education Institution, Lagjja KALABRIA p.n., Prishtinë, Kosovë \\ 10000 Prishtina, Kosovo \\ shkumbin.asllani@ubt-uni.net
}

\begin{abstract}
Determination of the residence it is a fundamental issues of international tax law appeared by the end of the $19^{\text {th }}$ century. 'Corporate residence' in terms of Article 4(1) of the OECD MC is fundamental to the application of the provision of the double tax treaties to establish the minimum nexus for taxing a person or a company in its own territory known as the residence principle. However, when it comes to the interpretation of the residence and defying it for tax purposes the concept "place of effective management" goes further into the Article 4(3) of the OECD MC aiming to solve the dual residence problems which may arise on domestic law by virtue of Article 4(1) OECD MC.
\end{abstract}

Key words: 'place of effective management', 'OECD MC', 'corporateresidence', 'tax treaty', 'residence principle'

\section{Introduction}

The double tax treaties use the residence principle to establish the minimum nexus for taxing a persons or a company in its own territory. The determination of the residence is a fundamental issues of international tax law appeared by the end of the $19^{\text {th }}$ century (Ceroni, 2012). "Place of Effective Management" is a tax legal concept that indicates a particular level of business activity in the residence and source country. The importance of the permanent establishment into a globalized economy is increasing, therefore, the place of effective management 'concept' it's intensively discussed in government bodies around the world as well as at the UN, EU and OECD level, in addition, the case laws has been increasing recently.

OECD Model Tax Convention on Income and on Capital on the Article 4(1) uses the notion 'corporate residence' as a fundamental notion to the provision of the double tax treaties between different countries. However, when it comes to the interpretation of the residence and defining it for tax purposes the concept "place of effective management" goes further into the Article 4(3) of the OECD MC aiming to solve the dual residence problems which may arise on domestic law by virtue of Article 4(1) OECD MC (OECD MC, 2014).

In a globalize economy and $21^{\text {st }}$ century technological development has enable companies to conduct business activities not only in the country were are legally registered but in numerous other countries, therefore, presently there is an increase activity of cross-border trade which are 
classifying a company as a resident in at least two countries. Consequently, increasing the double taxation based on the residence-residence conflict.

OECD in particular has developed guiding principles on eliminating or mitigation the double taxation. In this respect Article 4 of the OECD MC gives an overview of resident country for the purposes to levy taxes. Yet, defining the residence country it might be a difficult task taking into account the mentioned reasons below, in particular it's difficult to interpret this on the light of Article 4(3) since for this tie-breaker provision to work properly should be understood on the same meaning by contracting countries.

Although in the view of many scholars, Article 4(3) of the OECD MC, as well as, the commentary to the OECD MC gives a set of guidelines and are well-established rules. However, various interpretations are still possible and different approaches are used by different contracting countries. (van den Berg, van der Gulik, 2009)

Following this lack of consistency in the interpretation of the concept in practice this paper with explore the main approaches to the interpretation on the limitations of the tie-breaker rule "place of effective management" in the light of Article 4(3) OECD MC.

\section{The Tie-Breaker Rule "Place of Effective Management" in the light of Article 4(3) an overview}

The determination of residence in tax treaty it's at ultimate importance. It is impossible to apply a tax treaty without defining the residence country, "all tax treats are based on the two concepts the residence state and the other state" (Berglund, Cejie 2014) In addition, the OECD MC in regard to tie-breaker rule in article 4(3) defines "the state of residence as the state in which the company has its place of effective management" (OECD MC, 2010).

The concept "place of effective management" it's further elaborated in the Commentary, stating "the place where key management and commercial decisions that are necessaryfor the conduct of the entity's business as a whole are in substance made. An entity may have more than one place of management, but it can have only one place of effective management at any one time". (Commentary to OECD MC, 2010). Additionally, the OECD MC assumes thatthis "criteria makes a clear decision possible and no other criterion is set out and there is no reference to the mutual agreement procedure". (Lang, 2012).

Article 1 of the OECD MC highlights that the personal scope of tax treaties depends on fiscal residency in one of the contracting states or both, while Article 4(1) refers to domestic law in order to define residence for tax purposes, whereas Article 4(3) specifies that the place of effective management its significant condition for companies (OECD MC, 2014). Even though the concept of "place of effective management" is important for companies, nonetheless, it had importance in the 'early days', the interpretation of the concept at the present time is persistently complicated.

It is important at this stage to mention the fact that it is commonly understood that the "place of effective management" for tax purposes is interested as the place where top level management in substance makes decisions and not where the decisions are implemented. The tie-breaker rule it's not based in personal attachment either in the purely formal criteria of registration (Discussion paper OECD MC, 2001). 


\section{Limitation of the Article 4(3) tie-break rule}

Every legal provision must be 'judged' by its capacity to solve exceptional cases. A numerous academic literature and articles has mentioned the fact of the inability of the tie-breaker rule to solve the main problems of the dual residence and this was even more strongly exemplified in the 2001 OECD - tag paper (Burgstaller, Haslinger, 2004). The main pressing legal issues listed by the 2001 OECD-tag paper will be further elaborated in the following structure of this paper.

- Multiple "place of effective management"

- Mobility of the "place of effective management"

- Problems encountered in triangular case

\section{Multiple "Place of Effective Management"}

An issue on determing the place of effective management according to the OECD TAG paper 2001 comes due to the fact of the increment of the technological aspects since it's possible for a managing director to take decision while being in different countries through conferencing and using the modern technology for communicating. (Discussion paper OECD MC, 2001). Further, it is evident that the transformation of companies from centralized hierarchies to decentralized networking operation and decision makings, as well as, the technological improvements has threatened the tiebreak success on determine the place of effective management. (Burgstaller, Haslinger, 2004)

Thus, the decision can be taken by the use of e-mail, videoconferencing and other electronic discussion where the person or persons do not meet in one place in order to make decision The use of technology and the transformation of companies in respect of decision making procedures complicated matters to located the place of management since, more than one person can dominate the process of decision-making, consequently the place of effective management can be in more than only one jurisdiction. Due to this fact of the limitation of the existing tie-break rule some scholars has express their opinion on revising the rule by adopting it to the circumstances.(Discussion paper OECD MC, 2001)

\section{Mobility of the "Place of Effective Management"}

The OECD-TAG paper has also address the issue of mobile place of effective management, according to the paper the managing director might takes decisions while flying. In addition, another scenario might be that the director makes decision on board a ship that is located in international waters, hence, the place of effective management can be a difficult task to be solve. (Burgstaller, Haslinger, 2004)

However, in this direction an analogy with respect to Article 8(3) of the OECD MC can be used. OECD MC Article8(3) highlights this matter by giving an importance to the "place of effective management" where the company it's located (OECD MC, 2014), however, due to linguistic differences in reference to the Article 4(3) and 8(3) might be the reason why the tie-breaker rule it's not extended to air transport enterprises. (Discussion paper OECD MC, 2001). 


\section{Problems encountered in triangular cases}

The limitation of the tie-breaker rule on determine the place of effective management of Article 4(3) OECD MC in a triangular cases become evident on the era of globalized market and due to the presence of multinational companies in more than just one jurisdiction. The current Article 4(3) operates effectively on determining the place of effective management in one of the two contracting states, but when a third state its involved this rule has limitations.(Lang, 2012)

Further, the limitation of the tie-breaker rule can be illustrated by an example; if there is a company resident of both contracting states (A and B) according to their domestic laws with its place of effective management in a third country (C) in this case the tie-breaker rule under the Article 4(3) of the OECD MC would be capable to solve the dual residence issues only under state A and C or B and C (Burgstaller, Haslinger, 2004). Due to the fact that Article 4(3) provides that an entity is a resident of both contracting states "it shall be deemed to be a resident only of the state in which its place of effective management is situated", hence, this definition might be imply that the company cannot be a resident of either state A or B, therefore, the current tie-breaker rule will not be able to solve the problem of the dual residence between the contracting states in this case A and B.(Lang, 2012). In addition, this is not satisfactory outcome of the tie-breaker rule in this respect.

This issue has been discussed by the Base Erosion and Profit Sharing report and is suggested that contracting states should solve the issue of "place of effective management" on a case-by-case basis. (Lang, 2012).

\section{Determining the "Place of Effective Management"}

Determining the "Place of Effective Management" has been a difficult task for contracting states as the fact of their reference in domestic law when it comes to interpretation of the tax treaties which in most of the cases do arise on double taxation issues as a final result. (Burgstaller, Haslinger, 2004). As a matter of fact, the problem of interpretation has been present as many countries tie in with similar concepts of residence in their domestic law.

Worldwide two approaches can be found when it comes to the determination of the place of effective management, the Anglo-American 'central management and control' and the Continental European 'place of management' concept (Burgstaller, Haslinger, 2004), which are going to be explained briefly in this chapter, as well as, an overview on the understanding of the place of effective management in traditional environments and the evaluation of the OECD MC in respect to the place of effective management will be elaborated.

\section{"Place of Effective Management" in a traditional environment}

As stated above the term "place of effective management" in the paragraph 24 of the Commentary on Article 4 gives an interpretation on the meaning of this term: "The place of effective management 
is the place where key management and commercial decisions that are necessary for the conduct of the enterprise's business are in substance made. The place of effective management will ordinarily be where the most senior person or group of persons (for example a board of directors) makes its decisions, the place where the actions to be taken by the enterprise as a whole are determined; however, no definitive rule can be given and all relevant facts and circumstances must be examined to determine the place of effective management. An enterprise may have more than one place of management, but it can have only one place of effective management at any one time."(Commentary to OECD MC, 2010)

According to scholars the commentary gives it quite clear that the determination of a place of effective management is a question of facts. However, this is not sufficient as a matter of fact the OECD MC also use the term of "place of effective management" in the respective articles 8, 13(3), 15(3) and 22(3) for allocation of taxing rights for different purposes, but, the term itself it's not defined (Discussion paper OECD MC, 2001). Therefore, many commentators in the absence of clear definition regarding the place of effective management have been influenced by concepts used in domestic tax law such "central management and control" as well as "place of management"(OECD Report, 2001) are going to be explained in further details below.

\section{"Central Management and Control"}

Central Management and Control it is a test which has been commonly adopted by lot of countries in order to determine the place of effective management of different companies, the application of this test it's a question of fact rather than a test of corporate residence in the light of law. The common law test of "central management and control" was set in the case De BeersConsolidates Mines, Limited vs Howe (De Beers v Howe(2005) K.B. 612), where an advantageon determining the place of effective management has been given to the fact of where central management and control is situated not necessarily the location of the board meetings. (Burgstaller, Haslinger, 2004)

\section{"Place of Management"}

On its decisions German BFH has decided that every company must have at least one place of management. (R 76/95) In addition, in Germany the place of management it is determined by the residence criteria.(German Tax Code). In Italy, Netherlands, Switzerland etc. the fiscal residence is often determined by their place of effective management. According to German domestic law a great importance on determining the place of management should be given to the decision on dayto-day management in terms of leading the business and operations, and not necessary including the participation of shareholders. (Burgstaller, Haslinger, 2004)

\section{Interpretation of the "Place of Effective Management" by states}

Countries tend to interpret the term of 'place of effective management' in their domestic context and difficulties arise due to the fact that different countries interpret the term differently. In this regard, the relevance of the 'real' meaning must be understood in light of the Vienna Convention on the Law of Treaties which emphasizes that: "A treaty should be interpreted in good faith and in 
accordance with the ordinary meaning to be given to the terms of the treaty in their context and in the light of its object and purpose". (VCLT, 1969)

In addition, case-to-case approach has solved the issue of defining the "place of effective management" in different ways by different states, below I have summarized the interpretation of some OECD member countries and non-member countries on the issue mention:

Italy: "holds the view that the place where the main and substantial activity of the entity is carried on is also to be taken into account when determining the place of effective management of a person other than an individual". (OECD MC, 2014)

France: "considers that the definition of the place of effective management in paragraph 24 according to which the place of effective management is the place where key management and commercial decision that are necessary for the conduct of the entity's business as a whole are in substance made, will generally correspond to the place where the person or group of persons who exercises the most senior function makes its decisions. It is the place where the organs of direction, management and control of the entity are, in fact, mainly located". (OECD MC, 2014)

Germany: "reserves the right to include a provision under which a partnership that is not a resident of a Contracting state according to the provisions of paragraph 1 is deemed to be a resident of the Contracting State where the place of its effective management is situated, but only to the extent that the income derived from the other contracting State or the capital situated in that other State is liable to tax in the first-mentioned State". (OECD MC, 2014)

Netherlands: "use the fact and circumstances criteria on determining the place of effective management giving an advantage to the place of ultimate managerial responsibilities over the place of day to day management". (OECD MC, 2014)

Armenia, Albania, Belarus etc: "reserve the right to include the place of incorporation or a similar criterion". (OECD MC, 2014)

From this overview the concept used by OECD member states and non-OECD member states can be easily understood the differences on the using of "place of effective management" under the Article 4(3) of the OECD MC, even though it is known that the Article 4(3) tie-breaker rule should have an autonomous meaning. However, the non-consistency of this meaning comes due to the lack of clear definition in the Commentary, as well as, the reference in domestic law by contracting countries to interpret the place of effective management.

\section{OECD evaluation of the "Place of Effective Management" concept}

In 1963, OECD put a draft of the concept of place of effective management which later on, in 1977 formed the basis of Article 4(3) MC and the Commentaries after. At this very first attempt of the OECD to clarify the determination of the place of effective management it could be noted that the Commentary gives an importance to the state where the company is "managed" rather than considering the other criteria such formal legal registration. (Commentary to OECD MC, 2010). Surely this was a vague concept on further determining the concept of place of effective management. As a consequence, countries interpreted the concept "place of effective management" in accordance with their domestic law which was not supported by the OECD. In this regard, the first major amendment to have an autonomous interpretation of the tie-breaker rule was made in 1992. However, the change proposed variation between the concepts of managed and controlled and place of effective management. (Commentary to OECD MC, 2010). Moreover, an attempt of OECD to have an autonomous interpretation of the term place of effective management is made in 2000 by 
updating the OECD MC and aiming to give more light to this issue, for this purpose a new sentence was added to support the management of both: board of directors and top-level executives. (Commentary to OECD MC, 2010) However, this was not an ideal solution because "board of directors" may have a different understanding in different countries. According to scholars' changes in 2000 seems to favor the common law test. Yet, despite continues efforts to clarify, the concept 'place of effective management' was still an 'issue' on determining the companies for tax purposes. In this regard, in 2001 OECD-TAG published the very first paper "The impact of the Communications Revolution on the Application of Place of Effective Management as a Tie-Breaker Rule" (Discussion paper OECD MC, 2001). This paper identifies the limitation of the concept at this century considering the advancement of the technological environment of companies, as well a number of recommendation has been given on possible solutions. In addition, this was followed by a discussion draft "Place of Effective Management Concept: Suggestions for changes to the OECD Model Tax Convention" which was publish in 2003(Discussion paper OECD, 2003). This discussion draft gave two options: a) Refining the existing tie-breaker rule by amending the OECD Commentary and b) Replacing the existing tie-breaker rule by a hierarchy of tests. The proposed expansion of the OECD MC and its Commentary was not supported by the OECD Member States. The OECD Members States were claiming that the first proposal gives an 'unjustified' priority to the place where the board of directors will have their meetings over the place where key management decision are taken by the senior management. Moreover, they found the second proposal as unnecessary. (van Raad, 2016/17) It was noted that Members States are giving an importance in the question of determining the "place of effective management" the case-by-case approach based on facts and circumstances of each case.

\section{Refining the existing tie-breaker rule}

As stated below the proposal on refining the existing tie-breaker rule was not supported due to the fact that its gives unjustified priority to the place where key management decision are taken by the senior management.

The concern was on the fact of unbalance section of Commentary in the model and was consider that; its gives undue emphasis to this fact, in addition, doesn't provide a resolution of the problem itself as well as fails to provide a balanced approach between the approaches of whether the decision made in form are in one location and in substance in another one.(C.F.E Opinion Statement, 2003) Therefore, it was concluded that the alternative proposals do not sufficiently provide practical resolution to the situation of dual corporate residence.

\section{Hierarchy of tests}

As mention previously the hierarchy of tests has been found 'unnecessary' by the OECD member states. In general, the OECD-TAG prosed to keep the "place of effective management" as the first test while introducing additional options which might be helpful on determining the place of effective management for companies which would follow the approach used for the tie-breaker rule for individuals (Burgstaller, Haslinger, 2004). 
According to OECD-TAG proposals four rules would apply to determining the "place of effective management": "a) it shall be deemed to be a resident only of the state in which its place of effective management is situated, b) If the State in which the "place of effective management" or it is found in neither (triangular cases) it shall be deemed a resident in the State in which the entity's economic relations are closer, c) If this cannot be determined then the authorities may have recourse to the State from the laws of which it derives its legal status, d) as a last option, if state or states from the laws of which it derives its legal status can't determine the place of effective management they should settle the dispute by mutual agreement." (OECD-TAG Discussion draft, 2003). However, the author keeps the opinion that option A and B leads to a different understanding between taxing rights granted to source and residence states, especially in cases where companies provide services at the same time in different jurisdictions. As for option C; comparable to the present test in terms of principles by offering practical resolution when secondary options need to be taken into account. As for the option D the alternative case-by-case approach impose no obligations on the authorities to settle possible problems by mutual agreement. (see also; C.F.E Opinion Statement, 2003). In addition, to the proposed 'options' linguistic terms should be analysed considering the words as "shall settle" as used rather than "shall endeavor" in respect to Article 4(2) used in case by case alternatives.

\section{Conclusion}

As previously mentioned the quality of any legal provision must be 'judged' by its capacity to solve exceptional cases. From the analyses made in previous chapters can be understood that there is a lack of a common understanding of the concept "place of effective management" which is a fundamental limitation of the tie-breaker rule, while the current Articles of the OECD MC and its Commentary has no 'productive' conclusion on the issue of determining the "place of effective management". Even thought, the current Article 4(3) of the OECD MC explains that "the place of effective management" it's the place where key management takes decision, however, no indication are made as to what level of management is appropriate for determining the place of effective management, therefore, lot of interpretation can be made, assuming the country in which the executive body operates or where the board of directors meet. Due to this fact, countries refer mostly in this situation to their domestic law.In addition, the limitation of the existing tie-breaker rule especially haven been 'visible' with the new technological equipment, as well as, the changes in the organizational structures of companies which are allowing directors to meet while they are in different countries. The fact that decentralized structure of companies makes able the same company to have more than one place of effective management, is another burden on determining the "place of effective management" in the light of Article 4(3) OECD MC. The existing tie-breaker rule come across its limitations in triangular situation as well. There are no provisions which makes it clear in situation where more than two jurisdictions are in question. In the previous chapters of this paper are elaborated the suggestions of the OECD on determining the "place of effective management". A major effort has been made in 2003 by OECD offering two options on determining the place of effective management on their discussion draft: a) Refining the existing tie-breaker rule by amending the OECD Commentary and b) Replacing the existing tie-breaker rule by a hierarchy of tests, however, both proposals were not supported by Members states by considering them 'unjustified' by giving a priority to the board of directors over the place where key management decision are taken respectively as 'unnecessary' change. Moreover, the OECD TAG proposals has been considered as weak to ensure unanimous view since differences in fiscal culture and corporate 
governance as well as in possible different interpretation of the term day to day management hasn't been consider seriously. (Burgers, 2007)

The capability of the existing tie-breaker rule under Article 4(3) of the OECD MC on solving disputes under the new ways of doing business are limited. However, we have to keep in mind that this issue was never an easy task, nevertheless, the globalized economy and development has enable companies to conduct their activities in many countries and as a consequence misusing and avoidance of taxation are possible risk when no autonomous interpretations takes place.

\section{Reference}

1. Martin Berglund \& Katia Cejie, Basics of International Taxation from a Methodological Point of View (iUSTUS FORLAG, 2014)

2. Michael Lang, Introduction to the Law of Double Taxation Convention (IBFD)

3. Michael Lang, Preventing Treaty Abuse Series on International Tax Law, Volume 10 (Linde)

4. Kess van Raad, Materials on International and EU Tax Law ( $4^{\text {th }}$ edition 2014, International Tax Center Leiden)

5. Eva Burgstaller and Katharina Haslinger, 'Place of Effective Management as a TieBreaker-Rule - Concept, Developments and Prospects'

6. Luca Verioni, 'The "Place of Effective Management" as a Connecting Factor for Companies' Tax Residence Within the EU vs the Freedom of Establishment: The Need for a Rethinking?'

7. Jean-Paul van den Berg and Bart van der Gulik, 'The Mutual Agreement Tiebreaker -

8. OECD and Dutch Perspectives'

9. I.J.J. Burgers, 'Some thoughts on Further Refinement of the Concept of Place of Effective Management for Tax Treaty Purposes'

10. C.F.E Opinion Statement, 'Place of Effective Management Concept - Suggestion for Changes to the OECD MC 2003'

11. OECD Model Tax Convention on Income and on Capital and its Commentary Version2014*, Convention between State A and State B with respect to Taxes in Income and on Capital

12. OECD Model Double Tax Convention on Income and Capital, Version 1977*

13. The impact of the Communications revolution on the application of "Place of Effective Management" as a tie breaker rule, February 2001

14. "Place of Effective Management" concept: Suggestions for changes to the OECD Model Tax Convention, May 2003

15. Taxation and Electronic Commerce, implementing the Ottawa taxation framework

16. Court of Appeal, De Beers Consolidated mines, Limited, Appellants; Home (Surveyor of Taxes) respondent (1905) 2 K.B. 612

17. Deutsches Steuerrecht v Entscheidungsdienst [1998] R 76/95

18. Vienna Convention on the Law of Treaties (with annex), Concluded at Vienna on 23May 1969 
19. German Federal Tax Code (Federal Law Gazette I p. 2178) 